\title{
Metabolomics Profile of Potato Tubers after Phosphite Treatment
}

\author{
Xingxi Gao1,2, Steven Locke³ ${ }^{3}$ Junzeng Zhang ${ }^{4}$, Jyoti Joshi' ${ }^{1}$, Gefu Wang-Pruski ${ }^{*}$ \\ ${ }^{1}$ Department of Plant, Food, and Environmental Sciences, Faculty of Agriculture, Dalhousie University, Truro, Canada \\ ${ }^{2}$ Department of Edible Fungi Science, Faculty of Agriculture, Ludong University, Yantai, China \\ ${ }^{3}$ Aquatic and Crop Resource Development Research Centre, National Research Council of Canada, Charlottetown, Canada \\ ${ }^{4}$ Aquatic and Crop Resource Development Research Centre, National Research Council of Canada, Halifax, Canada \\ Email: ^gefu.wang-pruski@dal.ca
}

How to cite this paper: Gao, X.X., Locke, S., Zhang, J.Z., Joshi, J. and Wang-Pruski, G. (2018) Metabolomics Profile of Potato Tubers after Phosphite Treatment. American Journal of Plant Sciences, 9, 845-864. https://doi.org/10.4236/ajps.2018.94065

Received: November 25, 2017

Accepted: March 25, 2018

Published: March 28, 2018

Copyright $\odot 2018$ by authors and Scientific Research Publishing Inc. This work is licensed under the Creative Commons Attribution International License (CC BY 4.0).

http://creativecommons.org/licenses/by/4.0/

(c) (i) Open Access

\begin{abstract}
Phosphite (Phi)-based fungicides are used to control the oomycete Phytophthora infestans which causes late blight disease, the most devastating disease in potatoes. In order to examine the effects of Phi-based fungicides on potato tubers through foliar or post-harvest application, a metabolite profiling approach based on gas chromatography coupled to mass spectrometry (GC-MS) has been established. A total of 132 metabolites were detected using the GC-MS approach. Among these, 34 metabolites were identified after normalization and annotated with a compound name with standard mass spectral library. Metabolomic analysis of Phi-treated plants showed significant differences in the levels of many metabolites especially amino acids. Multivariate statistical approaches, such as principal component analysis (PCA) and partial least squares discriminant analysis (PLS-DA), were employed to explore the relationships between metabolites to detect group differences. A good discrimination between the control and the Phi-treated plants was observed, which demonstrated that significant changes in the metabolite profile have been caused by the two different Phi applications (foliar or post-harvest). This finding suggests that the alteration of specific metabolite levels by accumulation of Phi can lead to resistance against the pathogen.
\end{abstract}

\section{Keywords}

Potato, Metabolomics, GC-MS, Phosphite, Phytophthora infestans

\section{Introduction}

Over the past decades, late blight caused by oomycete Phytophthora infestans, has been considered the most devastating disease triggering serious loss to pota- 
to production [1]. Widespread use of fungicides was a much preferred method to prevent the disease development and spread. Because of the harmful impact on the environment and human health, and high costs of fungicides, there is a need to develop alternative biocompatible methods to control late blight disease [1].

Several earlier molecular studies have shown that plants enhanced resistance when treated with defense inducing agents such as $\beta$-aminobutyric acid (BABA), thiadiazole-7-carbothioc acid S-methyl ester (BTH), and thiamine (vitamin B1) before pathogen attack [2]-[7]. Ton et al. [6] reported that BABA induces resistance against a broad spectrum of biotic and abiotic stresses in which cyclin-dependent kinase-like protein is responsible for BABA-activated defense in Arabidopsis. Similarly, BTH stimulates defense reactions in a number of crops against bacterial, fungal and viral pathogens [8]. Ahn et al. [2] showed that thiamine induces systemic acquired resistance (SAR) in horticultural crops, preventing several diseases caused by semi-biotrophic and biotrophic pathogens. Recently, another resistance inducing agent, phosphite $\left(\mathrm{H}_{2} \mathrm{PO}_{3}^{-}, \mathrm{Phi}\right)$, was found to produce significant suppression to $P$. infestans, both by direct inhibitory effect on the mycelial growth and indirect activation of defense mechanisms [9] [10] [11]. The direct mode of action of Phi was also reported by other researchers [12]-[19]. They demonstrated that the concentration of Phi in treated plants is directly related to the concentration of fungicide applied where Phi suppresses pathogen development directly through a fungitoxic effect. King et al. [16] reported that Phi inhibits the function of the cytoskeleton and cell wall synthesis in P. cinnamomi. On the other hand, indirect effects of Phi involve priming the plant immune system by inducing defense responses in plants that are susceptible to the oomycete pathogens [9] [18]-[24]. In agriculture, Phi-based fungicides are used to control a large number of oomycete pathogens, such as $P$. infestans [9] [25] [26], $P$. cinnamomi [27], $P$. plurivora [28], $P$. palmivora [29], and $P$. cactorum [30] in potato, lupin, European beech, papaya and peach, respectively. Because of its effectiveness [31] and easiness to be degraded by soil bacteria, it has been identified as low risk to human health and environment, and therefore, an alternative to conventional fungicides in many developed countries, such as USA, Canada, Australia, New Zealand and UK [32]. The currently registered Phi fungicide products include Confine ${ }^{\mathrm{TM}}$ (Winfield Solutions, LLC, St. Paul, MN, USA), Phostrol ${ }^{\bullet}$ (Engage Agro, Guelph, ON, Canada) and Rampart (Loveland Products, Loveland, CO, USA).

Because of substantial roles of Phi-based fungicides in plant resistance against pathogens, Phi can indirectly or directly affect plant metabolic pathways and thus affect the levels of metabolites. A comprehensive study of metabolite changes in response to Phi will increase our knowledge of plant defense responses, interactions between metabolic networks and basic plant metabolism. Metabolic profiling has been applied to study plant metabolism over the past several years [33]. It allows detection of chemically varied bioactive molecules 
and unknown compounds, as well as provides functional information on metabolic phenotypes of plants [34] [35].

Although the effect of Phi-based fungicides in controlling late blight disease on leaves and tubers has been studied using different potato cultivars [26] [31] [36] [37] [38] [39] [40], knowledge on the cause of the protective effect of Phi on plant metabolites is limited. To understand the complexity of Phi-induced resistance, it is necessary to analyse the highly complex mixtures of compounds in potatoes. The purpose of the present study is to apply metabolite profiling using gas chromatography coupled to mass spectrometry (GC-MS) to understand the possible effect of Phi application on potato plant growth and metabolism. GC-MS is a widely spread, rapid and reliable approach for metabolite profiling of highly complex biological matrixes, such as plant extracts. For the first time, Roessner et al. [41] developed a GC-MS method for the simultaneous analysis of polar metabolites (including amino acids, organic acids, sugars, and sugar alcohols) in potato tubers. In this study, we investigated the foliar and post-harvest applications of Phi on potato tubers. Comparison of metabolite profiles among the different treatments could help us to understand the mechanisms of Phi-based fungicides on potato tubers.

\section{Materials and Methods}

\subsection{Plant Material and Field Trial}

The potato (Solanum tuberosum L.) cultivar Russet Burbank (RB) seed tubers were planted in the research plot of Cavendish Farms (http://www.cavendishfarms.com) in 2015 (GPS location: 46.4285, -63.6820; New Annan, Prince Edward Island, Canada). Russet Burbank is an old potato variety, released in 1874 in North America for table and processing. The field was designed as a split plot, with one half of the potatoes without Phi treatment, another half treated with Phi-based fungicide Confine ${ }^{\mathrm{rm}}$ [45.8\% mono- and di-potassium salts of phosphorous acid $\left(\mathrm{KH}_{2} \mathrm{PO}_{3}\right.$ and $\left.\mathrm{K}_{2} \mathrm{HPO}_{3}\right)$ ], each of them containing four replications. Confine $\mathrm{e}^{\mathrm{Tm}}$ was sprayed 3 times during the season at standard rate of $5.8 \mathrm{~L} / \mathrm{Ha}$. The first spray took place 4 weeks after the emergence; and the subsequent sprays took place at 2 weeks intervals. The control plots were not sprayed with Confine. Tuber samples harvested from foliar Confine treated plot were named as PFT. After harvest, the tubers from the non-treated plot were treated with either water (named as PC) or Confine ${ }^{\mathrm{Tm}}$ (diluted at a 1:4.3 ratio with water, as recommended by the manufacture (Winfield Solutions, LLC), named as PPT). Cortex tissues from each tuber were collected and immediately frozen in liquid nitrogen prior to storage at $-80^{\circ} \mathrm{C}$ until further processing. Each of these three groups of samples (PC, PFT and PPT) consisted of 10 replications, 2 tubers per replication, in total 30 replications and 60 tubers.

\subsection{Metabolite Extraction, Derivatization and GC-MS Analysis}

Cortex tissues were analyzed from a total of 60 potatoes for both polar and 
non-polar metabolites extractions. Ten milligram of frozen tissues per each tuber were ground into a fine powder using a mortar and pestle in liquid nitrogen and transferred into a $4 \mathrm{~mL}$ glass vial with a Teflon-lined screw cap. The metabolites were extracted based on a published method [42]. The sample powder was mixed with a solution containing methanol/water/chloroform $(4: 1: 2, \mathrm{v} / \mathrm{v} / \mathrm{v})$ $(2.1 \mathrm{~mL})$ and $40 \mu \mathrm{L}$ of triacontane $(1 \mathrm{mg} / \mathrm{mL})$ as a non-polar internal standard. The samples were vortexed thoroughly and incubated at $50^{\circ} \mathrm{C}$ for $1 \mathrm{~h}$. After cooling to room temperature, $0.9 \mathrm{~mL}$ of water and $20 \mu \mathrm{L}$ of ribitol $(2 \mathrm{mg} / \mathrm{mL}$ in water), as a polar internal standard, were added to the vial. Each sample was vortexed again and incubated for another $1 \mathrm{~h}$ at room temperature. The samples were centrifuged $(2900 \mathrm{~g})$ for $30 \mathrm{~min}$ at $4^{\circ} \mathrm{C}$, and the non-polar and polar layers were collected separately. The non-polar layer was dried under a stream of nitrogen while the polar (aqueous) layer was dried in a speed vacuum concentrator. For derivatization, the dried polar and non-polar extracts were directly dissolved in $50 \mu \mathrm{L}$ methoxyamine- $\mathrm{HCl}(20 \mathrm{mg} / \mathrm{mL}$ in pyridine $)$ and $50 \mu \mathrm{L}$ of pyridine, respectively, and incubated at $50^{\circ} \mathrm{C}$ until the extract was totally re-dissolved. Metabolites were then derivatized further with the addition of $50 \mu \mathrm{L}$ of $\mathrm{N}$-Methyl- $\mathrm{N}$-(trimethylsilyl) trifluoroacetamide (MSTFA) $+1 \%$ trimethylchlorosilane (TMCS) and incubated at $50^{\circ} \mathrm{C}$ for $1 \mathrm{~h}$. The derivatized samples were ready for GC-MS analysis.

\subsection{GC-MS Analysis and Metabolite Identification}

GC separations were done on Agilent 6890 system using a DB-1ms column from Agilent (pn122-0132). The column dimensions were as follows: length of $30 \mathrm{~m}$, $0.25 \mathrm{~mm}$ ID and $0.25 \mu \mathrm{m}$ coating thickness. The inlet temperature was $250^{\circ} \mathrm{C}$. A $1 \mu \mathrm{L}$ injection was split 5:1. The column was operated at a flow rate of 1.0 $\mathrm{mL} / \mathrm{min}$ helium. The column oven was heated at $70^{\circ} \mathrm{C}$ for $5 \mathrm{~min}$ and then increased at $4^{\circ} \mathrm{C} / \mathrm{min}$ to $310^{\circ} \mathrm{C}$ where it was held for $11 \mathrm{~min}$. The column outlet was sent to a capillary flow technology (CFT) splitter whereby signal for MS (using Agilent 5973) and Flame Ionization Detector (FID) could be acquired simultaneously. Typical GC-MS (TIC) (a) and GC-FID (b) profiles for representative samples are shown in Figure 1. The MS source was at $250^{\circ} \mathrm{C}$ with 70 $\mathrm{eV}$. After a 5.5 min solvent delay, spectra were acquired for the mass range 50 $600 \mathrm{~m} / \mathrm{z}$ at $2.69 \mathrm{scans} / \mathrm{sec}$. The FID was operated at $280^{\circ} \mathrm{C}$ with hydrogen at 40 $\mathrm{mL} / \mathrm{min}$, air at $450 \mathrm{~mL} / \mathrm{min}$ and nitrogen (the makeup gas) at $20 \mathrm{~mL} / \mathrm{min}$. GC-FID/MS data were processed using Agilent ChemStation (ver. E.02.00493). Metabolites were identified by comparing ionization patterns with standards in NIST library (National Institute of Standards and Technology mass spectral library, NIST 05a.L). The integrated signal of the total ion current for each peak was compared between samples after normalization. Metabolites were normalized first using the internal standard and then the tissue weight.

\subsection{Data Reduction, Pattern Recognition and Statistical Analysis}

The GC-MS data were normalized to total spectral area and centered scaling was 


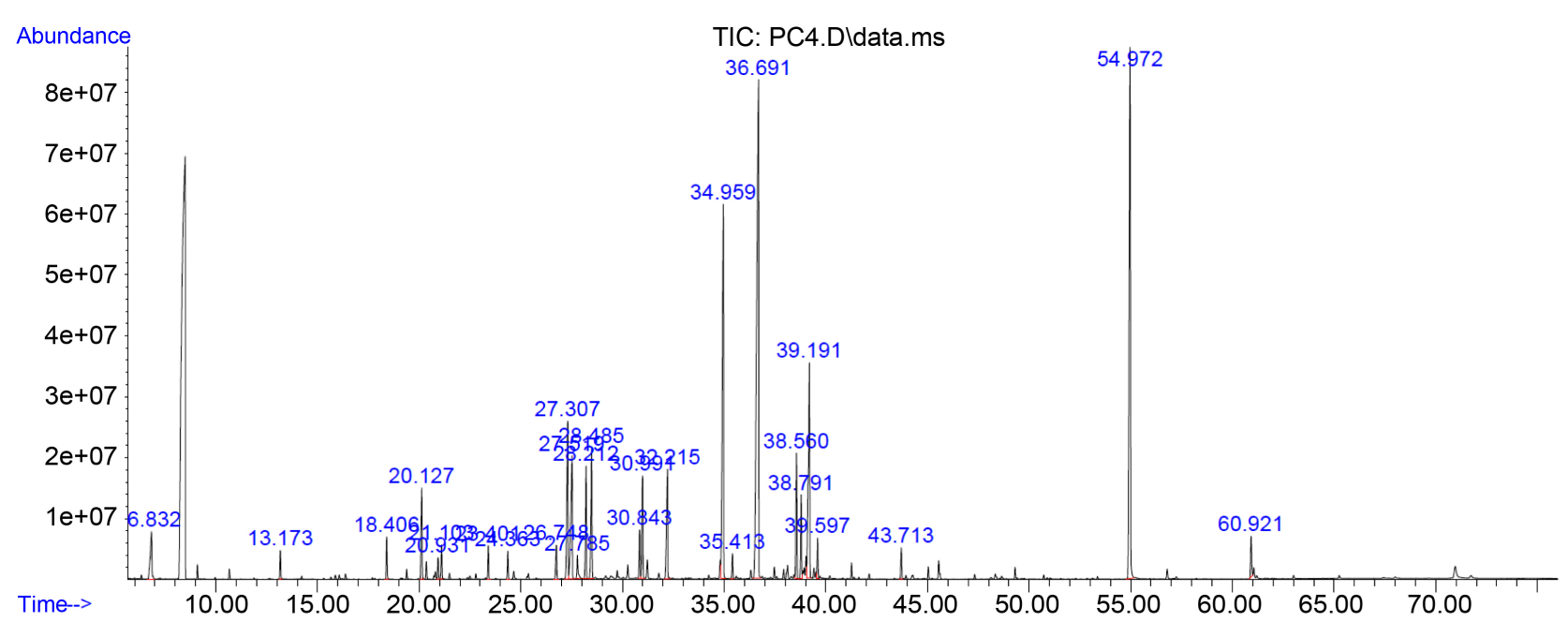

(a)

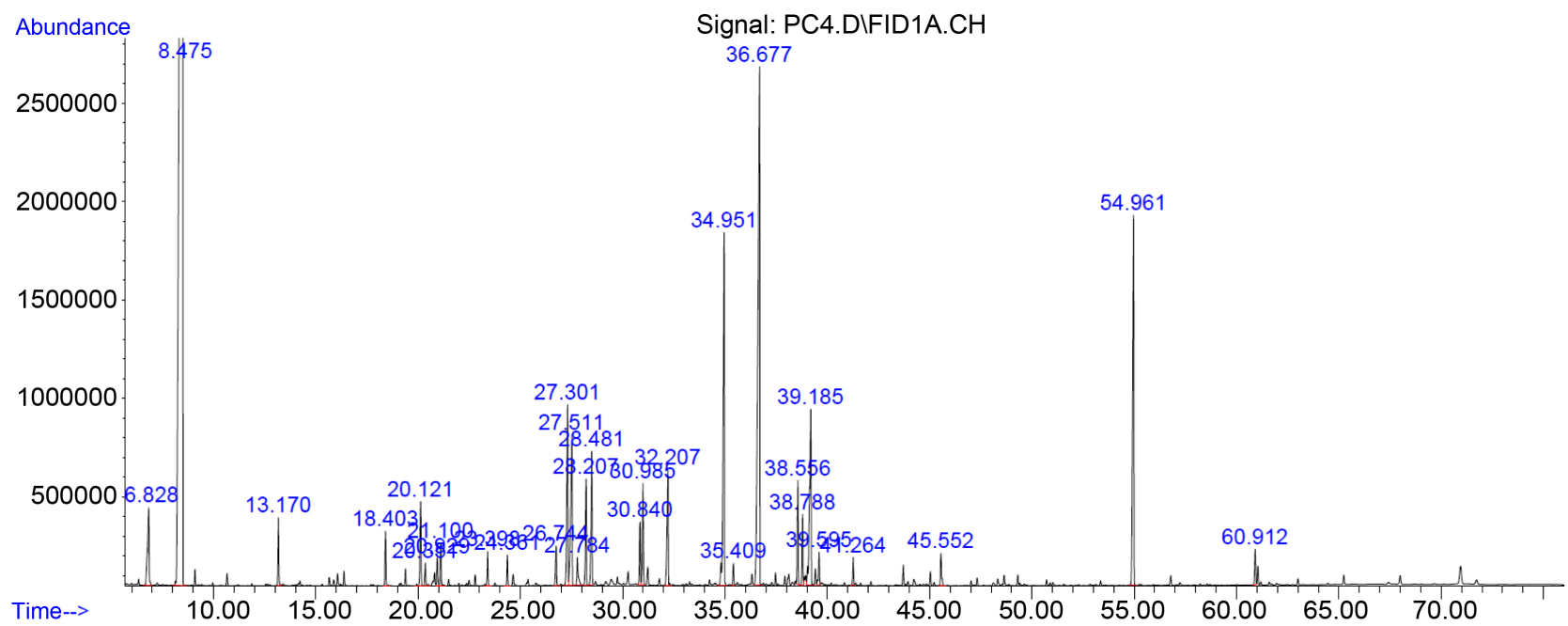

(b)

Figure 1. Typical GC-MS (TIC) (a) and GC-FID (b) profiles for representative samples.

applied before pattern recognition analyses. The resulted three-dimensional data involving the peak number, sample name, and normalized peak area were fed to SIMCA-P 11.5 software package (Umetrics, Umea, Sweden) for principal component analysis (PCA). Since the data of PC3 sample from the control group seemed much different from the other nine replications in the same group, possibly due to a failed GC-MS analysis, therefore, it was discarded in all following analyses. Data were visualized by using the principal component (PC) score plots. To maximize separation between the control and both Phi-treated samples, partial least squares discriminant analysis (PLS-DA) was performed. PLS-DA is a multivariate classification method based on PLS, the regression extension of PCA. Further statistical analysis of variance (ANOVA) with Tukey test was performed using Minitab software to define those showing statistically significant differences between the treatments. Metabolites were selected as showing statistically significant differential expression among the groups. 


\section{Results and Discussion}

\subsection{Metabolites Identified}

To investigate the effect of Phi application on potato tubers, GC-MS analysis was employed to perform global metabolite profiling to compare the control samples (PC) with the Phi-treated samples, either by field foliar treatment (PFT) or by post-harvest treatment (PPT). A total of 132 (75 in polar and 67 in non-polar) metabolites were detected using the GC-MS approach; however, only 34 metabolites were identified after normalization and annotated with a compound name with standard mass spectral library (Supplementary Table S1) and some major metabolites identified were listed in the Table 1 . These metabolites represented a complex mixture of chemicals that are separated as four main classes of compounds: amino acids, organic acids, sugars, and sugar alcohols. The number of metabolites identified and the level of coverage are relatively low in comparison to Abu-Nada et al. [43] who identified 95 polar metabolites including amino acids, fatty acids, organic acids and sugars in potato leaves following pathogen $P$. infestans inoculation. Similarly, a total of 180 polar and non-polar metabolites were identified in potato tubers by Shepherd et al. [44]. This has been a common problem faced by many researchers when using global or untargeted GC-MS metabolomics studies. Due to limited duration of the project and funding, the study was based on a one-year field trial. To compensate this shortcoming, 10 replications in each treatment was used in order to generate reliable data.

\subsection{Data Reduction and Pattern Recognition}

To provide comparative interpretations and visualization of metabolic changes under various treatments, PCA was firstly applied to the GC-MS spectral datasets. PCA showed the distribution of original data, and the discriminations between the control group (PC) and the Phi-treated groups (PFT and PPT) were demonstrated by the PCA score plots (Figure 2). A good discrimination between the PC and the PFT and PPT was observed from the PCA score plots, which demonstrated that significant changes in the metabolite profile have been caused by the two different Phi treatments. However, as the score plot indicated (Figure 2(b)), the sample (PPT1) situated outside the confidence ellipse, and then it was

Table 1. Metabolites in the four groups detected by GC-MS in this study.

\begin{tabular}{ll}
\hline Compound classes & Metabolites \\
\hline \multirow{2}{*}{ Amino acids } & $\begin{array}{l}\text { alanine, asparagine, aspartic acid, glycine, glutamine, } \\
\text { isoleucine, leucine, methionine, phenylalanine, } \\
\text { proline, serine, threonine, tyrosine, valine }\end{array}$ \\
Organic acids & citric acid, cis-aconitic acid, benzoic acid, butanoic acid, \\
palmitic acid, stearic acid citrulline \\
Sugars & D-fructose \\
& glycerol, inositol
\end{tabular}




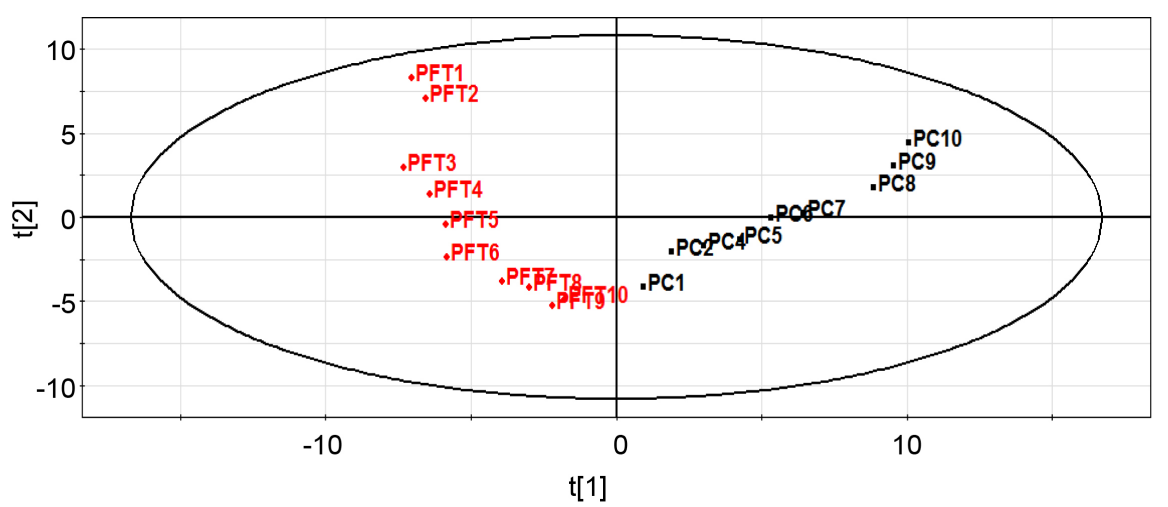

(a)

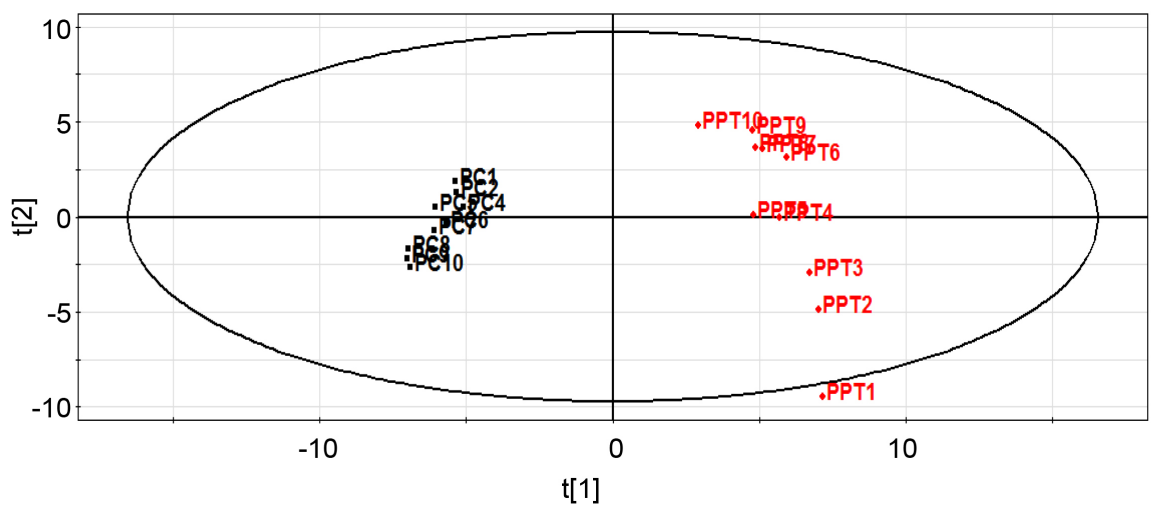

(b)

Figure 2. Score plots of principal component analysis (PCA) model obtained from polar metabolites between treatment groups. (a) PCA plot $\left(\mathrm{R}^{2} \mathrm{X}=0.88, \mathrm{Q}^{2}(\mathrm{cum})=0.73\right.$ ) between PC (control group) and PFT (field foliar treatment); (b) PCA plot $\left(\mathrm{R}^{2} \mathrm{X}=0.90\right.$, $\mathrm{Q}^{2}($ cum $\left.)=0.64\right)$ between PC (control group) and PPT (post-harvest treatment).

discarded for further analysis. In order to obtain a higher level of group separation and get a better understanding of variables responsible for classification, a supervised PLS-DA was applied, which showed a significant discrimination of the control group and both of the Phi-treated groups (Figure 3). This model worked better, and the PLS-DA model explained and predicted $97.2 \%$ and $87.6 \%$ for PFT group of the data according to the cross-validation, and explained and predicted $99.2 \%$ and $97.6 \%$ for PPT group, respectively, which were stable.

\subsection{Amino Acid Changes from Different Treatment Groups}

Analysis of variance (Tukey test, $P<0.05$ ) within the different classes of compounds was performed using Minitab software. A total of 24 metabolites including amino acids (14), organic acids (7), sugars (1), and sugar alcohols (2) showed a significant difference (Tukey, $P<0.05$ ) in abundance among treatments. The most prominent group of metabolites that showed differences across treatments was found to be amino acids. The amount of amino acids aspartic acid, leucine, methionine, serine, and threonine were significantly increased in both Phi-treated groups (PFT and PPT) compared to the control group (PC), whereas 


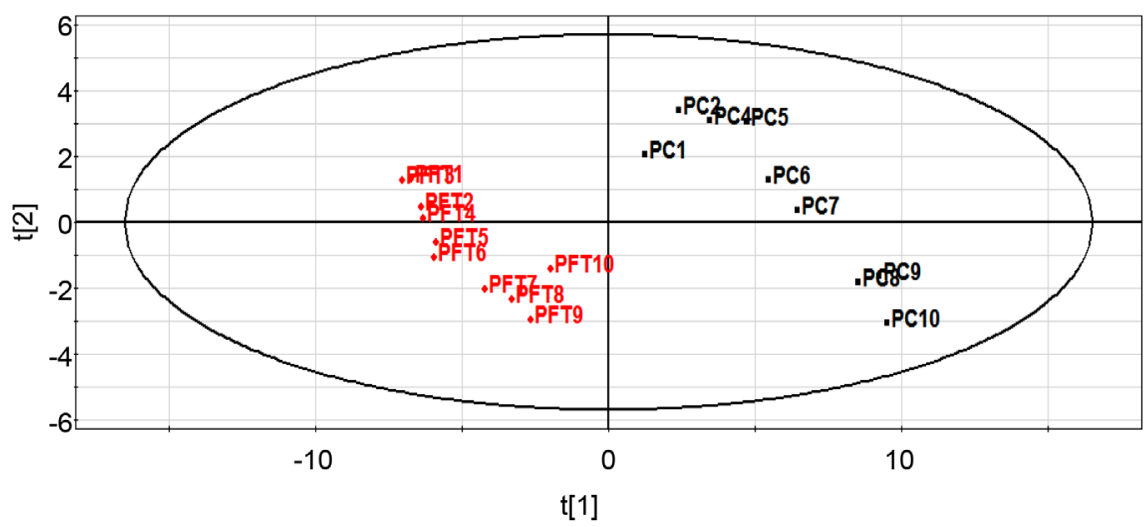

(a)

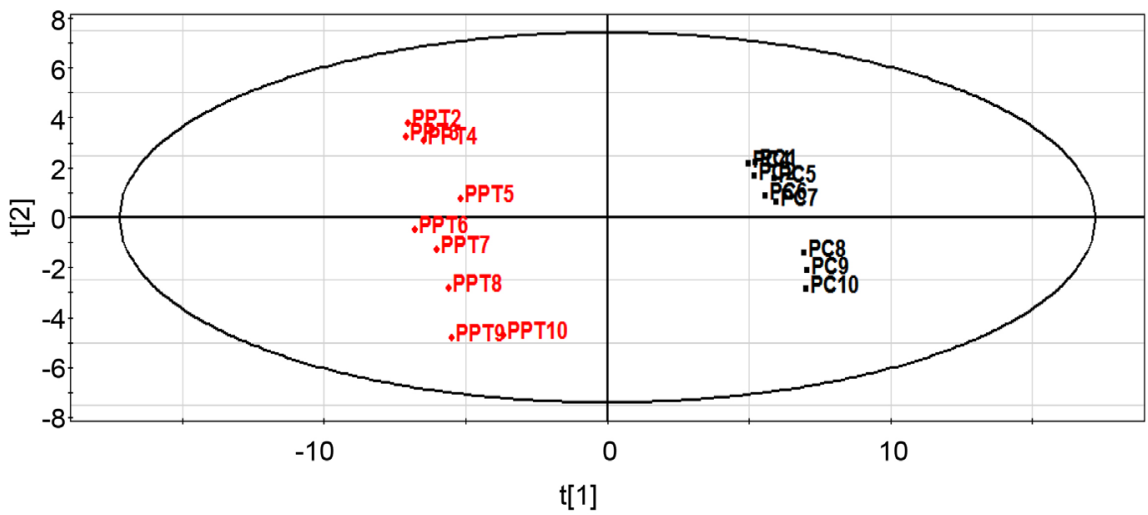

(b)

Figure 3. Score plots of partial least squares discriminant analysis (PLS-DA) model obtained from polar metabolites between treatment groups. (a) PLS-DA plot $\left(\mathrm{R}^{2} \mathrm{X}=0.58\right.$, $\mathrm{R}^{2} \mathrm{Y}=0.97, \mathrm{Q}^{2}$ (cum) $=0.88$ ) between PC (control group) and PFT (field foliar treatment); (b) PLS-DA plot $\left(\mathrm{R}^{2} \mathrm{X}=0.66, \mathrm{R}^{2} \mathrm{Y}=0.99, \mathrm{Q}^{2}(\mathrm{cum})=0.98\right.$ ) between $\mathrm{PC}$ (control group) and PPT (post-harvest treatment).

the amount of the amino acids alanine, asparagine, glutamine and valine were found to be decreased (Figure 4(a)) in Phi-treated plants. It has been well reported that alterations in the quantity of amino acids derived from the aspartate pathway have been identified to be important for resistance against oomycete pathogen like H. Arabidopsis and bacterial pathogen like Pseudomonas syringae [45] [46] [47]. Similarly, Berkowitz et al. [48] found that the accumulation of Phi affects the metabolism in Arabidopsis, leading to specifically changes in the levels of aspartate and the related amino acids asparagine and glutamate, and summarized that these changes in the amino acids are important for phosphite-induced resistance against oomycte pathogens. Although there were such complicated changes among different treatments in amino acid quantity, when a closer attention is paid to both Phi-treated groups, differences within the PFT and PPT groups were also noticed. In this case, the amino acids leucine, methionine, serine and threonine were significantly higher in post-harvest treatment (PPT) than in foliar treatment (PFT) according to Tukey test (Figure 4(a)); while the level of amino acids glycine and valine were significantly decreased in PPT as 


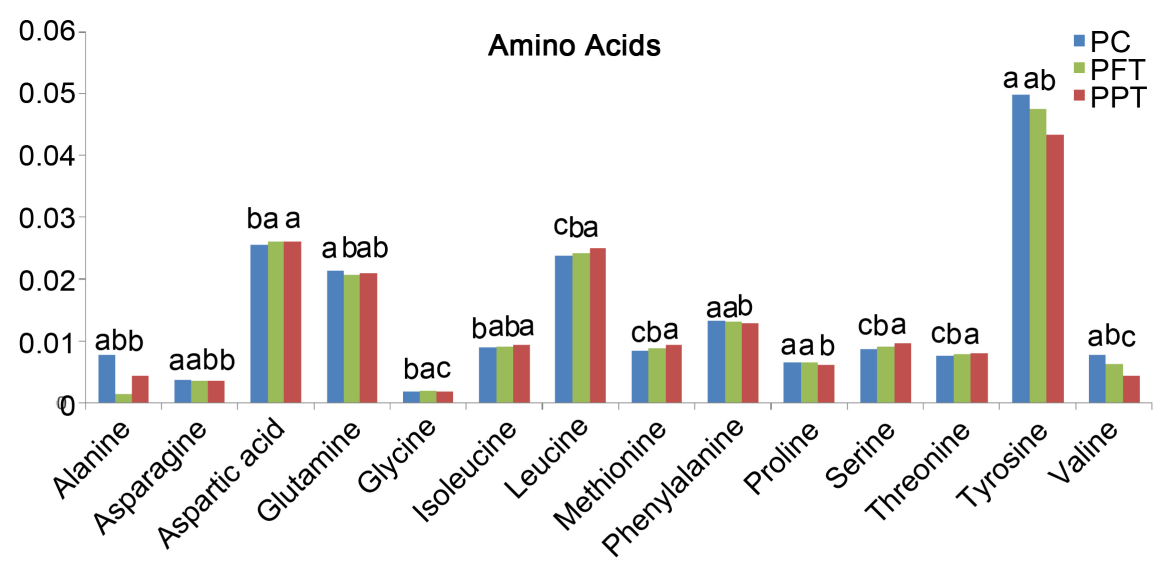

(a)

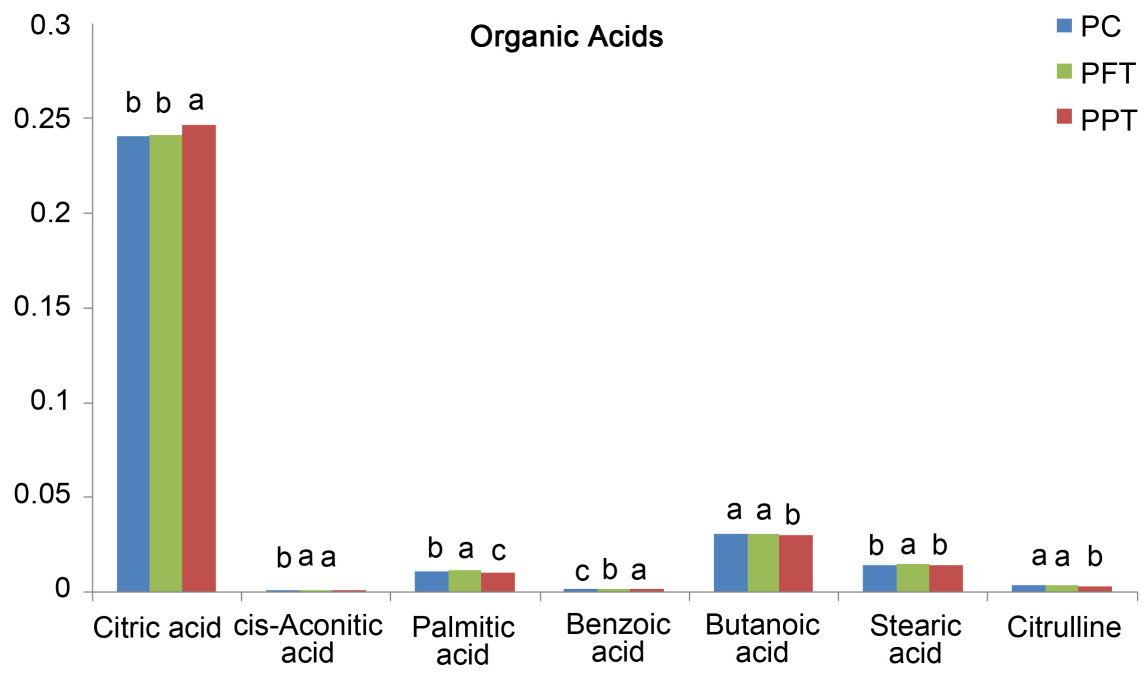

(b)

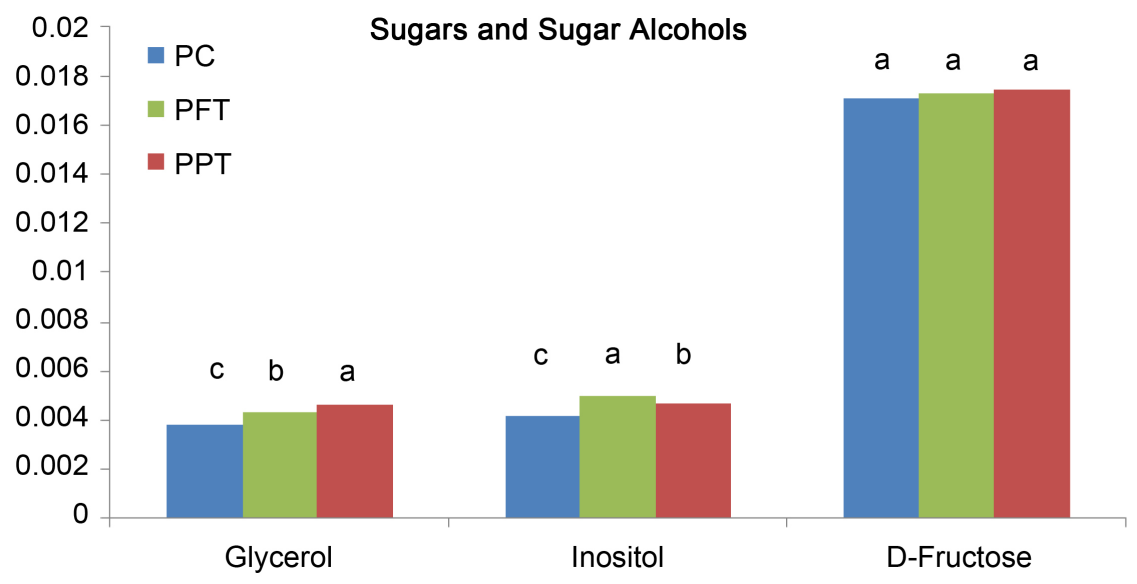

(c)

Figure 4. Changes of various metabolites in quantity (relative peak area) responding to Phi treatments in three different groups, Control (PC), field foliar treatment (PFT), and post-harvest treatment (PPT) in potato tubers. Letters ((a), (b), (c)) show significant differences among the groups and samples sharing the same letter are not significantly different according to Tukey test using Minitab software. The unit for $\mathrm{Y}$ axis is metabolite peak area/IS peak area (normalized for tissue weight). 
compared to the PFT treatment. Furthermore, the amount of amino acids isoleucine, phenylalanine, proline, and tyrosine did not change in the PFT treated samples compared to the control, but significantly decreased in the PPT treated samples. Amino acid glycine showed a marked increase in the PFT treated samples, but significantly decreased in the PPT treated samples as compared to the control. The reason for this increase of glycine in PFT may be due to that glycine is also formed by glyoxylate during photorespiration. In leaves, photorespiration provides metabolites for other metabolic processes, e.g. glycine for the synthesis of glutathione, which is also involved in stress protections [49] [50] [51]. The amino acids isoleucine, leucine and valine are important in the production of plant defense secondary metabolites such as cyanogenic glycosides, and glucosinolates [52]. Lim et al. [9] examined the direct effect of Phi application on potato leaves using comparative proteomics and identified significant changes in quantity of proteins after Phi treatment in potato leaves. They reported that down-regulated proteins were involved in metabolism and energy functions, such as amino acid metabolism, starch metabolism, photosynthesis, glycolysis and tricarboxylic acid (TCA) cycle; whereas majority up-regulated proteins were defense-related and associated with the salicylic acid (SA) dependent pathway, antimicrobial activity, the ROS pathway, the $\mathrm{Ca}^{2+}$ dependent pathway and the hypersensitivity reaction (HR). We found in this study that Phi induced changes in levels of alanine and the abundance of valine, glutamine and asparagine were reduced in the Phi-treated plants. This result is consistent with the report by Lim et al. [9]. Many studies have also demonstrated a role of amino acids in the establishment of resistance against plant pathogens [46] [48] [53], and that the alteration of specific metabolite levels by feeding or genetic manipulation of plant metabolic pathways can lead to resistance against pathogens. Grenville-Briggs et al. [54] identified that the biosynthesis of many amino acids was up-regulated in plants by fungi and oomycetes during biotrophic growth and also reported that genes involved in the biosynthesis of methionine, tryptophan, threonine, and branched-chain amino acids were up-regulated in plants after infection.

\subsection{Organic Acid Changes from Different Treatment Groups}

The second group of metabolites showing significant changes responding to the Phi treatments was organic acids. Citric acid was significantly up-regulated in the PPT group, whereas cis-aconitic acid and benzoic acid were up-regulated in both Phi-treated (PFT and PPT) tubers as compared to the control (PC) (Figure 4(b)). In general, citric acid has frequently been found to be increased under phosphorus deficiency, which might act as a strategy to improve phosphorus uptake from the soil [55]. Interestingly, differences between the two Phi-treated groups (PFT and PPT) were also noticed among these organic acids. For instance, the quantity of palmitic acid, butanoic acid, and citrulline were decreased in the PPT as compared to the PFT group (Figure 4(b)). Decreased palmitic acid was also reported to be associated with Phi treatment. Citric acid has an impor- 
tant role in TCA cycle which is considered to be a primordial pathway for production of starting organic molecules for biosynthesis of sugars, amino acids, pyrimidines and lipids. Benzoic acid, derived from phenylalanine, is a precursor to several important benzenoid compounds, including floral scent constituents, such as phenylethyl benzoate, benzyl benzoate, methyl benzoate [56] [57], the defense signalling compounds SA and its derivatives [58] [59], and a number of pharmacologically active compounds, such as taxol [60]. It has been well reported that Phi-based fungicides enhanced the expression of defense genes whose products are involved in SA and jasmonic acid (JA) pathways in Arabidopsis [22]. Several studies have reported an increased level of benzoic acids in Phi-treated plants [9] [20] [21] [22] [23] [24]. Correspondingly, we were able to observe changes for the organic acids among the treatments.

\subsection{Sugar and Sugar Alcohol Changes from Different Treatment Groups}

Differences in D-fructose were found to be non-significant in all the three treatments according to ANOVA (Figure 4(c)). However, sugar alcohols, such as glycerol and inositol, were all significantly up-regulated in response to Phi treatments (both in PFT and PPT) as compared to the control (PC). It has been well documented that glycerol plays an important role in the biosynthesis of glycerol-3-phosphate (G3P) through glycerokinase, and that G3P is an important metabolite that contributes to the growth and disease-related physiology of plants. Chanda et al. [61] reported that G3P serves as the inducer of an important form of broad-spectrum immunity in plants, termed systemic acquired resistance (SAR). SAR is induced upon primary infection and protects distal tissues from secondary infections. Inositol is an intermediate in the biosynthesis and degradation of the phosphate-storage compound phytate [62], so the increase of inositol might indicate the mobilization of phosphate from, or a reduced flux into, storage pools [48].

Lovatt and Mikkelsen [63] also reported that Phi may influence sugar metabolism, cause internal hormonal and chemical changes, and induce the SA pathway, resulting in increased floral intensity, and fruit yield and quality in various crops including onions, potatoes and tomatoes. Burra et al. [24] investigated transcriptome analysis of potatoes after Phi treatment and found that transcripts associated with defense, wounding, and oxidative stress constituted the core of the Phi response. They also observed changes in primary metabolism and cell wall related processes. Although several studies have reported the negative effects of Phi on the growth of plants [64]-[69], its mode of action at the molecular level is not fully understood [23] [70]. Even though the proteomic analysis [9], transcriptomic profiling [24] and high-performance ion chromatography (HPIC) method [10] have been used for assessing the accumulation of $\mathrm{Phi}$ in potato tubers, a detailed study of metabolite changes in response to Phi can increase our understanding of plant defense responses, interactions between metabolic networks and basic plant metabolism. Metabolomics is a powerful 
approach to gain a comprehensive perspective of how metabolic networks are regulated and has increasingly been applied by many researchers in recent years. It can be used to elucidate the functions of genes and complements transcript profiling and proteomic in functional genomics and systems biology [71] [72].

The main limitation of the GC-MS profiling is that it can only measure volatile compounds or compounds that can be volatilized following chemical derivatization. The other approaches such as liquid chromatography-mass spectrometry (LC-MS) and capillary electrophoresis-mass spectrometry (CE-MS) provide better alternatives for non-volatile compound analysis [73] [74] [75]. The current study is the first to investigate plant metabolites in the two, foliar or post-harvest Phi treatments (PFT and PPT), including amino acids, organic acids and sugar alcohols in potatoes. Analysis of a number of metabolites showed differences in their quantity. Since a large number of peaks could not be identified by using the NIST library alone, we were restricted regarding the number of metabolites that could be analysed in the samples. Our earlier proteomic profiling study using Phi [9] confirmed that proteins related to metabolisms of amino acids, organic acids and carbohydrates in potatoes have been regulated. Our on-going work on gene expression profiling by RNA sequencing may further provide detailed data in enriching this study.

Although the number of metabolites detected was small in this study, the results showed the capability of metabolite profiling, clustering and statistical analyses to identify potential metabolite differences in the Phi-treated groups compared to the control group. This study provided us with a more comprehensive view of the metabolites and increased our understanding of Phi-induced resistance of plants to oomycete pathogens.

\section{Conclusion}

The GC-MS based metabolomic approach was used to examine the effects of Phi applications on potato tubers through foliar or post-harvest application. Significant differences were identified in the levels of many metabolites including amino acids, organic acids, and sugars. These results demonstrated the potential role of Phi-based fungicides in altering the abundance of specific metabolites in potato tubers, which provided a novel insight in our understanding of the mechanism of Phi induced resistance of potato tubers to pathogens, especially $P$. infestans.

\section{Acknowledgements}

Funding for this research was provided by Nova Scotia Department of Agriculture Research Acceleration Program, project number RA2013-0035. The Metabolomics Innovation Centre (TMIC) in Alberta, Canada has assisted in the identification of metabolites.

\section{References}

[1] Haverkort, A., Boonekamp, P., Hutten, R., Jacobsen, E., Lotz, L., Kessel, G., Visser, 
R. and Van der Vossen, E. (2008) Societal Costs of Late Blight in Potato and Prospects of Durable Resistance through Cisgenic Modification. Potato Research, 51, 47-57. https://doi.org/10.1007/s11540-008-9089-y

[2] Ahn, I.P., Kim, S. and Lee, Y.H. (2005) Vitamin B1 Functions as an Activator of Plant Disease Resistance. Plant Physiology, 138, 1505-1515.

https://doi.org/10.1104/pp.104.058693

[3] Goellner, K. and Conrath, U. (2008) Priming: It's All the World to Induced Disease Resistance. European Journal of Plant Pathology, 121, 233-242. https://doi.org/10.1007/s10658-007-9251-4

[4] Oostendorp, M., Kunz, W., Dietrich, B. and Staub, T. (2001) Induced Disease Resistance in Plants by Chemicals. European Journal of Plant Pathology, 107, 19-28. https://doi.org/10.1023/A:1008760518772

[5] Shimono, M., Sugano, S., Nakayama, A., Jiang, C.J., Ono, K., Toki, S. and Takatsuji, H. (2007) Rice WRKY45 Plays a Crucial Role in Benzothiadiazole-Inducible Blast Resistance. The Plant Cell, 19, 2064-2076. https://doi.org/10.1105/tpc.106.046250

[6] Ton, J., Jakab, G., Toquin, V., Flors, V., Iavicoli, A., Maeder, M.N., Métraux, J.P. and Mauch-Mani, B. (2005) Dissecting the $\beta$-Aminobutyric Acid-Induced Priming Phenomenon in Arabidopsis. The Plant Cell, 17, 987-999.

https://doi.org/10.1105/tpc.104.029728

[7] Zimmerli, L., Métraux, J.P. and Mauch-Mani, B. (2001) $\beta$-Aminobutyric Acid-Induced Protection of Arabidopsis against the Necrotrophic Fungus Botrytis cinerea. Plant Physiology, 126, 517-523. https://doi.org/10.1104/pp.126.2.517

[8] Tally, A., Oostendorp, M., Lawton, K., Staub, T., Bassi, B. and Agrawal, A. (1999) Commercial Development of Elicitors of Induced Resistance to Pathogens. Induced Plant Defenses against Pathogens and Herbivores. Biochemistry, Ecology, and Agriculture, 357-369.

[9] Lim, S., Borza, T., Peters, R.D., Coffin, R.H., Al-Mughrabi, K. I., Pinto, D.M. and Wang-Pruski, G. (2013) Proteomics Analysis Suggests Broad Functional Changes in Potato Leaves Triggered by Phosphites and a Complex Indirect Mode of Action against Phytophthora infestans. Journal of Proteomics, 93, 207-223.

https://doi.org/10.1016/j.jprot.2013.03.010

[10] Borza, T., Schofield, A., Sakthivel, G., Bergese, J., Gao, X., Rand, J. and Wang-Pruski, G. (2014) Ion Chromatography Analysis of Phosphite Uptake and Translocation by Potato Plants: Dose-Dependent Uptake and Inhibition of Phytophthora infestans Development. Crop Protection, 56, 74-81.

https://doi.org/10.1016/j.cropro.2013.10.024

[11] Borza, T., Peters, R., Wu, Y., Schofield, A., Rand, J., Ganga, Z., Al-Mughrabi, K., Coffin, R. and Wang-Pruski, G. (2017) Phosphite Uptake and Distribution in Potato Tubers Following Foliar and Postharvest Applications of Phosphite-Based Fungicides for Late Blight Control. Annals of Applied Biology, 170, 127-139. https://doi.org/10.1111/aab.12322

[12] Smillie, R., Grant, B. and Guest, D. (1989) The Mode of Action of Phosphite: Evidence for Both Direct and Indirect Modes of Action on Three Phytophthora spp. in Plants. Phytopathology, 79, 921-926. https://doi.org/10.1094/Phyto-79-921

[13] McDonald, A.E., Grant, B.R. and Plaxton, W.C. (2001) Phosphite (Phosphorous Acid): Its Relevance in the Environment and Agriculture and Influence on Plant Phosphate Starvation Response. Journal of Plant Nutrition, 24, 1505-1519. https://doi.org/10.1081/PLN-100106017

[14] Thao, H.T.B., Yamakawa, T., Myint, A.K. and Sarr, P.S. (2008) Effects of Phosphite, 
a Reduced Form of Phosphate, on the Growth and Phosphorus Nutrition of Spinach (Spinacia oleracea L.). Soil Science \& Plant Nutrition, 54, 761-768. https://doi.org/10.1111/j.1747-0765.2008.00290.x

[15] Thao, H.T.B. and Yamakawa, T. (2009) Phosphite (Phosphorous Acid): Fungicide, Fertilizer or Bio-Stimulator? Soil Science \& Plant Nutrition, 55, 228-234. https://doi.org/10.1111/j.1747-0765.2009.00365.x

[16] King, M., Reeve, W., Van der Hoek, M.B., Williams, N., McComb, J., O’Brien, P.A. and Hardy, G.E.S.J. (2010) Defining the Phosphite-Regulated Transcriptome of the Plant Pathogen Phytophthora cinnamomi. Molecular Genetics and Genomics, 284, 425-435. https://doi.org/10.1007/s00438-010-0579-7

[17] Lobato, M., Olivieri, F., Daleo, G. and Andreu, A. (2010) Antimicrobial Activity of Phosphites against Different Potato Pathogens/Antimikrobielle Aktivität von Phosphiten gegenüber verschiedenen Kartoffelpathogenen. Journal of Plant Diseases and Protection, 117, 102-109. https://doi.org/10.1007/BF03356343

[18] Machinandiarena, M.F., Lobato, M.C., Feldman, M.L., Daleo, G.R. and Andreu, A.B. (2012) Potassium Phosphite Primes Defense Responses in Potato against Phytophthora infestans. Journal of Plant Physiology, 169, 1417-1424. https://doi.org/10.1016/j.jplph.2012.05.005

[19] Olivieri, F., Feldman, M., Machinandiarena, M., Lobato, M., Caldiz, D., Daleo, G. and Andreu, A. (2012) Phosphite Applications Induce Molecular Modifications in Potato Tuber Periderm and Cortex That Enhance Resistance to Pathogens. Crop Protection, 32, 1-6. https://doi.org/10.1016/j.cropro.2011.08.025

[20] Molina, A., Hunt, M.D. and Ryals, J.A. (1998) Impaired Fungicide Activity in Plants Blocked in Disease Resistance Signal Transduction. The Plant Cell, 10, 1903-1914. https://doi.org/10.1105/tpc.10.11.1903

[21] Friedrich, L., Lawton, K., Dietrich, R., Willits, M., Cade, R. and Ryals, J. (2001) NIM1 Overexpression in Arabidopsis Potentiates Plant Disease Resistance and Results in Enhanced Effectiveness of Fungicides. Molecular Plant-Microbe Interactions, 14, 1114-1124. https://doi.org/10.1094/MPMI.2001.14.9.1114

[22] Eshraghi, L., Anderson, J., Aryamanesh, N., Shearer, B., McComb, J., Hardy, G. and O'brien, P. (2011) Phosphite Primed Defence Responses and Enhanced Expression of Defence Genes in Arabidopsis thaliana Infected with Phytophthora cinnamomi. Plant Pathology, 60, 1086-1095. https://doi.org/10.1111/j.1365-3059.2011.02471.x

[23] Massoud, K., Barchietto, T., Le Rudulier, T., Pallandre, L., Didierlaurent, L., Garmier, M., Ambard-Bretteville, F., Seng, J.M. and Saindrenan, P. (2012) Dissecting Phosphite-Induced Priming in Arabidopsis Infected with Hyaloperonospora arabidopsidis. Plant Physiology, 159, 286-298. https://doi.org/10.1104/pp.112.194647

[24] Burra, D.D., Berkowitz, O., Hedley, P.E., Morris, J., Resjö, S., Levander, F., Liljeroth, E. and Alexandersson, E. (2014) Phosphite-Induced Changes of the Transcriptome and Secretome in Solanum tuberosum Leading to Resistance against Phytophthora infestans. BMC Plant Biology, 14, 254. https://doi.org/10.1186/s12870-014-0254-y

[25] Lobato, M., Olivieri, F., Altamiranda, E.G., Wolski, E., Daleo, G., Caldiz, D. and Andreu, A. (2008) Phosphite Compounds Reduce Disease Severity in Potato Seed Tubers and Foliage. European Journal of Plant Pathology, 122, 349-358. https://doi.org/10.1007/s10658-008-9299-9

[26] Lobato, M.C., Machinandiarena, M.F., Tambascio, C., Dosio, G.A., Caldiz, D.O., Daleo, G.R., Andreu, A.B. and Olivieri, F.P. (2011) Effect of Foliar Applications of Phosphite on Post-Harvest Potato Tubers. European Journal of Plant Pathology, 130, 155-163. https://doi.org/10.1007/s10658-011-9741-2 
[27] Groves, E., Howard, K., Hardy, G. and Burgess, T. (2015) Role of Salicylic Acid in Phosphite-Induced Protection against Oomycetes; A Phytophthora cinnamomi-Lupinus augustifolius Model System. European Journal of Plant Pathology, 141, 559-569. https://doi.org/10.1007/s10658-014-0562-y

[28] Dalio, R.J., Fleischmann, F., Humez, M. and Osswald, W. (2014) Phosphite Protects Fagus sylvatica Seedlings towards Phytophthora plurivora via Local Toxicity, Priming and Facilitation of Pathogen Recognition. PLOS ONE, 9, e87860. https://doi.org/10.1371/journal.pone.0087860

[29] Vawdrey, L. and Westerhuis, D. (2007) Field and Glasshouse Evaluations of Metalaxyl, Potassium Phosphonate, Acibenzolar and Tea Tree Oil in Managing Phytophthora Root Rot of Papaya in Far Northern Queensland, Australia. Australasian Plant Pathology, 36, 270-276. https://doi.org/10.1071/AP07016

[30] Thomidis, T. and Elena, K. (2001) Effects of Metalaxyl, Fosetyl-Al, Dimethomorph and Cymoxanil on Phytophthora cactorum of Peach Tree. Journal of Phytopathology, 149, 97-101. https://doi.org/10.1046/j.1439-0434.2001.00584.x

[31] Wang-Pruski, G., Coffin, R.H., Peters, R.D., Al-Mughrabi, K.I., Platt, H.W., Pinto, D., Veenhuis-MacNeill, S., Hardy, W., Lim, S. and Astatkie, T. (2010) Phosphorous Acid for Late Blight Suppression in Potato Leaves. The Americas Journal of Plant Science and Biotechnology, 4, 25-29.

[32] Kromann, P., Pérez, W.G., Taipe, A., Schulte-Geldermann, E., Sharma, B.P., Andrade-Piedra, J.L. and Forbes, G.A. (2012) Use of Phosphonate to Manage Foliar Potato Late Blight in Developing Countries. Plant Disease, 96, 1008-1015. https://doi.org/10.1094/PDIS-12-11-1029-RE

[33] Wishart, D.S. (2008) Metabolomics: Applications to Food Science and Nutrition Research. Trends in Food Science \& Technology, 19, 482-493. https://doi.org/10.1016/j.tifs.2008.03.003

[34] Kopka, J. (2006) Current Challenges and Developments in GC-MS Based Metabolite Profiling Technology. Journal of Biotechnology, 124, 312-322. https://doi.org/10.1016/j.jbiotec.2005.12.012

[35] Torras-Claveria, L., Berkov, S., Jáuregui, O., Caujapé, J., Viladomat, F., Codina, C. and Bastida, J. (2010) Metabolic Profiling of Bioactive Pancratium canariense Extracts by GC-MS. Phytochemical Analysis, 21, 80-88. https://doi.org/10.1002/pca.1158

[36] Cooke, L.R. and Little, G. (2002) The Effect of Foliar Application of Phosphonate Formulations on the Susceptibility of Potato Tubers to Late Blight. Pest Management Science, 58, 17-25. https://doi.org/10.1002/ps.408

[37] Johnson, D.A., Inglis, D.A. and Miller, J.S. (2004) Control of Potato Tuber Rots Caused by Oomycetes with Foliar Applications of Phosphorous Acid. Plant Disease, 88, 1153-1159. https://doi.org/10.1094/PDIS.2004.88.10.1153

[38] Andreu, A.B., Guevara, M.G., Wolski, E.A., Daleo, G.R. and Caldiz, D.O. (2006) Enhancement of Natural Disease Resistance in Potatoes by Chemicals. Pest Management Science, 62, 162-170. https://doi.org/10.1002/ps.1142

[39] Mayton, H., Myers, K. and Fry, W. (2008) Potato Late Blight in Tubers-The Role of Foliar Phosphonate Applications in Suppressing Pre-Harvest Tuber Infections. Crop Protection, 27, 943-950. https://doi.org/10.1016/j.cropro.2007.11.014

[40] Gachango, E., Kirk, W.W. and Schafer, R. (2012) Effects of In-Season Crop-Protection Combined with Postharvest Applied Fungicide on Suppression of Potato Storage Diseases Caused by Oomycete Pathogens. Crop Protection, 41, 42-48.

https://doi.org/10.1016/j.cropro.2012.04.010 
[41] Roessner, U., Wagner, C., Kopka, J., Trethewey, R.N. and Willmitzer, L. (2000) Simultaneous Analysis of Metabolites in Potato Tuber by Gas Chromatography-Mass Spectrometry. The Plant Journal, 23, 131-142. https://doi.org/10.1046/j.1365-313x.2000.00774.x

[42] Yang, W.L. and Bernards, M.A. (2007) Metabolite Profiling of Potato (Solanum tuberosum L.) Tubers during Wound-Induced Suberization. Metabolomics, 3, 147-159. https://doi.org/10.1007/s11306-007-0053-7

[43] Abu-Nada, Y., Kushalappa, A., Marshall, W., Al-Mughrabi, K. and Murphy, A. (2007) Temporal Dynamics of Pathogenesis-Related Metabolites and Their Plausible Pathways of Induction in Potato Leaves Following Inoculation with Phytophthora infestans. European Journal of Plant Pathology, 118, 375-391. https://doi.org/10.1007/s10658-007-9150-8

[44] Shepherd, T., Dobson, G., Verrall, S.R., Conner, S., Griffiths, D.W., McNicol, J.W., Davies, H.V. and Stewart, D. (2007) Potato Metabolomics by GC-MS: What Are the Limiting Factors? Metabolomics, 3, 475-488. https://doi.org/10.1007/s11306-007-0058-2

[45] Návarová, H., Bernsdorff, F., Döring, A.C. and Zeier, J. (2012) Pipecolic Acid, an Endogenous Mediator of Defense Amplification and Priming, Is a Critical Regulator of Inducible Plant Immunity. The Plant Cell, 24, 5123-5141. https://doi.org/10.1105/tpc.112.103564

[46] Stuttmann, J., Hubberten, H.M., Rietz, S., Kaur, J., Muskett, P., Guerois, R., Bednarek, P., Hoefgen, R. and Parker, J.E. (2011) Perturbation of Arabidopsis Amino Acid Metabolism Causes Incompatibility with the Adapted Biotrophic Pathogen Hyaloperonospora arabidopsidis. The Plant Cell, 23, 2788-2803. https://doi.org/10.1105/tpc.111.087684

[47] van Damme, M., Zeilmaker, T., Elberse, J. andel, A., de Sain-van der Velden, M. and van den Ackerveken, G. (2009) Downy Mildew Resistance in Arabidopsis by Mutation of Homoserine Kinase. The Plant Cell, 21, 2179-2189. https://doi.org/10.1105/tpc.109.066811

[48] Berkowitz, O., Jost, R., Kollehn, D.O., Fenske, R., Finnegan, P.M., O’Brien, P.A., Hardy, G.E.S.J. and Lambers, H. (2013) Acclimation Responses of Arabidopsis thaliana to Sustained Phosphite Treatments. Journal of Experimental Botany, 64, 1731-1743. https://doi.org/10.1093/jxb/ert037

[49] Noctor, G., Arisi, A.C.M., Jouanin, L. and Foyer, C.H. (1999) Photorespiratory Glycine Enhances Glutathione Accumulation in Both the Chloroplastic and Cytosolic Compartments. Journal of Experimental Botany, 50, 1157-1167. https://doi.org/10.1093/jxb/50.336.1157

[50] Noctor, G., Arisi, A.C.M., Jouanin, L., Kunert, K.J., Rennenberg, H. and Foyer, C.H. (1998) Glutathione: Biosynthesis, Metabolism and Relationship to Stress Tolerance Explored in Transformed Plants. Journal of Experimental Botany, 49, 623-647. https://doi.org/10.1093/jxb/49.321.623

[51] Noctor, G., Arisi, A.C.M., Jouanin, L., Valadier, M.H., Roux, Y. and Foyer, C.H. (1997) Light-Dependent Modulation of Foliar Glutathione Synthesis and Associated Amino Acid Metabolism in Poplar Overexpressing $\gamma$-Glutamylcysteine Synthetase. Planta, 202, 357-369. https://doi.org/10.1007/s004250050138

[52] Coruzzi, G. and Last, R. (2000) Light and Carbon Metabolism Regulate the Assimilation of Nitrogen into Amino Acids. In: Buchanan, B.B., Gruissem, W. and Jones, R.L., Eds., Biochemistry and Molecular Biology of Plants, American Society of Plant Physiologists, Rockville, 376-377. 
[53] Hwang, I.S., An, S.H. and Hwang, B.K. (2011) Pepper Asparagine Synthetase 1 (CaAS1) Is Required for Plant Nitrogen Assimilation and Defense Responses to Microbial Pathogens. The Plant Journal, 67, 749-762. https://doi.org/10.1111/j.1365-313X.2011.04622.x

[54] Grenville-Briggs, L.J., Avrova, A.O., Bruce, C.R., Williams, A., Whisson, S.C., Birch, P.R. and van West, P. (2005) Elevated Amino Acid Biosynthesis in Phytophthora infestans during Appressorium Formation and Potato Infection. Fungal Genetics and Biology, 42, 244-256. https://doi.org/10.1016/j.fgb.2004.11.009

[55] Koyama, H., Kawamura, A., Kihara, T., Hara, T., Takita, E. and Shibata, D. (2000) Overexpression of Mitochondrial Citrate Synthase in Arabidopsis Thaliana Improved Growth on a Phosphorus-Limited Soil. Plant and Cell Physiology, 41, 1030-1037. https://doi.org/10.1093/pcp/pcd029

[56] Azuma, H., Toyota, M., Asakawa, Y., Takaso, T. and Tobe, H. (2002) Floral Scent Chemistry of Mangrove Plants. Journal of Plant Research, 115, 0047-0053.

https://doi.org/10.1007/s102650200007

[57] Boatright, J., Negre, F., Chen, X., Kish, C.M., Wood, B., Peel, G., Orlova, I., Gang, D., Rhodes, D. and Dudareva, N. (2004) Understanding in Vivo Benzenoid Metabolism in Petunia Petal Tissue. Plant Physiology, 135, 1993-2011. https://doi.org/10.1104/pp.104.045468

[58] Lu, H. (2009) Dissection of Salicylic Acid-Mediated Defense Signaling Networks. Plant Signaling \& Behavior, 4, 713-717. https://doi.org/10.4161/psb.4.8.9173

[59] Vlot, A.C., Dempsey, D.M.A. and Klessig, D.F. (2009) Salicylic Acid, a Multifaceted Hormone to Combat Disease. Annual Review of Phytopathology, 47, 177-206. https://doi.org/10.1146/annurev.phyto.050908.135202

[60] Walker, K. and Croteau, R. (2000) Taxol Biosynthesis: Molecular Cloning of a Benzoyl-CoA: Taxane $2 \alpha$-O-Benzoyltransferase cDNA from Taxus and Functional Expression in Escherichia coli. Proceedings of the National Academy of Sciences, 97, 13591-13596. https://doi.org/10.1073/pnas.250491997

[61] Chanda, B., Xia, Y., Mandal, M.K., Yu, K., Sekine, K.T., Gao, Q.M., Selote, D., Hu, Y., Stromberg, A. and Navarre, D. (2011) Glycerol-3-phosphate Is a Critical Mobile Inducer of Systemic Immunity in Plants. Nature Genetics, 43, 421-427. https://doi.org/10.1038/ng.798

[62] Raboy, V. (2003) Myo-Inositol-1,2,3,4,5,6-hexakisphosphate. Phytochemistry, 64, 1033-1043. https://doi.org/10.1016/S0031-9422(03)00446-1

[63] Lovatt, C. and Mikkelsen, R. (2006) Phosphite Fertilizers: What Are They? Can You Use Them? What Can They Do. Better Crops, 90, 11-13.

[64] Carswell, C., Grant, B.R., Theodorou, M.E., Harris, J., Niere, J.O. and Plaxton, W.C. (1996) The Fungicide Phosphonate Disrupts the Phosphate-Starvation Response in Brassica nigra Seedlings. Plant Physiology, 110, 105-110. https://doi.org/10.1104/pp.110.1.105

[65] Carswell, M.C., Grant, B.R. and Plaxton, W.C. (1997) Disruption of the Phosphate-Starvation Response of Oilseed Rape Suspension Cells by the Fungicide Phosphonate. Planta, 203, 67-74. https://doi.org/10.1007/s00050166

[66] Ticconi, C.A., Delatorre, C.A. and Abel, S. (2001) Attenuation of Phosphate Starvation Responses by Phosphite in Arabidopsis. Plant Physiology, 127, 963-972. https://doi.org/10.1104/pp.010396

[67] Varadarajan, D.K., Karthikeyan, A.S., Matilda, P.D. and Raghothama, K.G. (2002) Phosphite, an Analog of Phosphate, Suppresses the Coordinated Expression of 
Genes under Phosphate Starvation. Plant Physiology, 129, 1232-1240. https://doi.org/10.1104/pp.010835

[68] Thao, H.T.B., Yamakawa, T., Myint, A.K. and Sarr, P.S. (2008) Effects of Phosphite, a Reduced Form of Phosphate, on the Growth and Phosphorus Nutrition of Spinach (Spinacia oleracea L.). Soil Science \& Plant Nutrition, 54, 761-768. https://doi.org/10.1111/j.1747-0765.2008.00290.x

[69] Thao, H.T.B., Yamakawa, T., Shibata, K., Sarr, P.S. and Myint, A.K. (2008) Growth Response of Komatsuna (Brassica rapa var. peruviridis) to Root and Foliar Applications of Phosphite. Plant and Soil, 308, 1. https://doi.org/10.1007/s11104-008-9598-0

[70] Jackson, T., Burgess, T., Colquhoun, I. and Hardy, G.S. (2000) Action of the Fungicide Phosphite on Eucalyptus marginata Inoculated with Phytophthora cinnamomi. Plant Pathology, 49, 147-154. https://doi.org/10.1046/j.1365-3059.2000.00422.x

[71] Bino, R.J., Hall, R.D., Fiehn, O., Kopka, J., Saito, K., Draper, J., Nikolau, B.J., Mendes, P., Roessner-Tunali, U. and Beale, M.H. (2004) Potential of Metabolomics as a Functional Genomics Tool. Trends in Plant Science, 9, 418-425. https://doi.org/10.1016/j.tplants.2004.07.004

[72] Krömer, J.O., Sorgenfrei, O., Klopprogge, K., Heinzle, E. and Wittmann, C. (2004) In-Depth Profiling of Lysine-Producing Corynebacterium glutamicum by Combined Analysis of the Transcriptome, Metabolome, and Fluxome. Journal of Bacteriology, 186, 1769-1784. https://doi.org/10.1128/JB.186.6.1769-1784.2004

[73] Giri, S., Krausz, K.W., Idle, J.R. and Gonzalez, F.J. (2007) The Metabolomics of $( \pm)$-arecoline 1-oxide in the Mouse and Its Formation by Human Flavin-Containing Monooxygenases. Biochemical Pharmacology, 73, 561-573. https://doi.org/10.1016/j.bcp.2006.10.017

[74] Granger, J.H., Williams, R., Lenz, E.M., Plumb, R.S., Stumpf, C.L. and Wilson, I.D. (2007) A Metabonomic Study of Strain- and Age-Related Differences in the Zucker Rat. Rapid Communications in Mass Spectrometry, 21, 2039-2045. https://doi.org/10.1002/rcm.3059

[75] Soga, T., Ohashi, Y., Ueno, Y., Naraoka, H., Tomita, M. and Nishioka, T. (2003) Quantitative Metabolome Analysis using Capillary Electrophoresis Mass Spectrometry. Journal of Proteome Research, 2, 488-494.

https://doi.org/10.1021/pr034020m 


\section{Supplementary}

Table S1. Tentative identification of major metabolites.

\begin{tabular}{|c|c|c|}
\hline $\begin{array}{l}\text { Peak RT } \\
\text { (min) }\end{array}$ & Metabolite & Derivative product identified by NIST MS library search \\
\hline \multicolumn{3}{|l|}{ Polar } \\
\hline 9.08 & Methanediimine & Silanamine, N,N'-methanetetraylbis[1,1,1-trimethyl $]$ \\
\hline 10.65 & Borate & Tris(trimethylsilyl)borate \\
\hline 13.19 & L-Valine & L-Valine, trimethylsilyl ester \\
\hline 15.87 & Buane & 3-Methyl-1,3-bis(trimethylsilyloxy)butane \\
\hline 18.40 & L-Valine & L-Valine, N-(trimethylsilyl)-, trimethylsilyl ester \\
\hline 20.12 & Phosphate & Silanol, trimethyl, phosphate $(3: 1)$ \\
\hline 20.92 & Proline & L-Proline, 1-(trimethylsllyl)-, trimethylsllyl ester \\
\hline 21.09 & Isoleucine & L-isoleucine, $\mathrm{N}$-(trimethylsilyl)-, trimethylsllyl ester \\
\hline 22.49 & Benzonic acid & Benzoic acid, 2-methyl-, trimethylsilyl ester \\
\hline 23.40 & Serine & Serine tritms \\
\hline 24.36 & L-threonine & N,O,O-Tris(trimethylsilyl)-L-threonine \\
\hline 24.65 & Asparagine & Asparagine \\
\hline 25.37 & B-alanine & B-alanine \\
\hline \multirow[t]{2}{*}{27.29} & Malic acid & Malic acid, O-(trimethylsilyl)-, bis(trimethysilyl)ester \\
\hline & Butanedioic acid & Butanedioic acid, [(trimethylsilyl)oxy], bis(trimethylsilyl) ester \\
\hline 27.51 & L-Proline & L-Proline, 5-oxo-1-(trimethylsilyl)-, trimethylsilyl ester \\
\hline 27.78 & L-methionine & L-Methionine, N-(trimethylsilyl)-, trimethysilyl ester \\
\hline 28.20 & L-Aspartic acid & L-Aspartic acid, N-(trimethylsilyl)-, bis(trimethylsilyl) ester \\
\hline 28.47 & Butanoic acid & Butanoic acid, 4-[bis(trimethylsilyl)amino]-, trimethylsilyl ester \\
\hline 30.84 & L-Phenylalanine & N,O-Bis(trimethylsilyl)-L-phenylalanine \\
\hline 30.98 & Glutamine & Glutamine, tris(trimethylsilyl)- \\
\hline 32.23 & L-Asparagine & L-Asparagine, N,N-bis(trimethylsilyl)-, trimethylsilyl ester \\
\hline 36.31 & Citrulline & Citrulline \\
\hline 36.68 & 1,2,3-Propanetricarboxylic acid & 1,2,3-Propanetricarboxylic acid, 2-[)trimethylsilyl)oxy]-, tris(trimethylsilyl) ester \\
\hline \multirow[t]{2}{*}{38.56} & D-Fructose & D-Fructose, 1,3,4,5,6-pentakis-O-(trimethylsilyl)-, O-methyloxime \\
\hline & D-Ribose & D-Ribose, 2,3,4,5-tetrakis-O-(trimethylsilyl)-, O-methyloxime \\
\hline \multirow[t]{2}{*}{38.78} & D-Fructose & D-Fructose, 1,3,4,5,6-pentakis-O-(trimethylsilyl)-, O-methyloxime \\
\hline & D-Ribose & D-Ribose, 2,3,4,5-tetrakis-O-(trimethylsilyl)-, O-methyloxime \\
\hline \multirow[t]{2}{*}{39.17} & D-Galactose & D-Galactose, 2,3,4,5,6-pentakis-O-(trimethylsilyl)-, O-methyloxyme, (1E)- \\
\hline & D-Glucose & D-Glucose, 2,3,4,5,6-pentakis-O-(trimethylsilyl)-, O-methyloxyme, (1E)- \\
\hline 41.26 & Hexadecanoic acid & Hexadecanoic acid, trimethylsilyl ester \\
\hline \multirow[t]{2}{*}{43.71} & Inositol & Inositol, 1,2,3,4,5,6-hexakis-O-(trimethylsilyl)-, scyllo- \\
\hline & Myo-inositol & Myo-inositol, 1,2,3,4,5,6-hexakis-O-(trimethylsilyl)- \\
\hline 45.55 & Octadecanoid acid & Octadecanoic acid, trimethylsilyl ester \\
\hline 54.96 & Sucrose & $\begin{array}{l}\text { Alpha-D-glucopyranoside, 1,3,4,6-tetrakis-O-(trimethylsilyl)-, } \\
\text { beta-D-fructofuranosyl-2,3,4,6-tetrakis-O-(trimethylsiyl)- }\end{array}$ \\
\hline
\end{tabular}




\section{Continued}

\begin{tabular}{|c|c|c|}
\hline 60.92 & Lactose & $\begin{array}{l}\text { D-Glucopyranose, 4-O-[2,3,4,6-tetrakis-O-(trimethylsilyl)-, } \\
\text { beta-D-galactopyranosyl]-1,2,3,6-tetrakis-O-(trimethylsilyl)- }\end{array}$ \\
\hline \multirow{3}{*}{70.95} & Melibiose & Melibiose, octakis(trimethylsilyl)- \\
\hline & Cellobiose & $\begin{array}{l}\text { D-glucose, } \\
\text { 4-O-[2,3,4,6-tetrakis-O-(trimethylsilyl)-beta-D-glucopyranosyl]-2,3,5,6-tetrakis-O-(trimethylsilyl)- }\end{array}$ \\
\hline & Maltose & Maltose, octakis(trimethylsilyl) \\
\hline \multicolumn{3}{|c|}{ Non-polar } \\
\hline 10.68 & Borate & Tris(trimethylsilyl)borate \\
\hline \multirow[t]{2}{*}{19.04} & $\begin{array}{l}\text { Benzene, } \\
\text { 2,3-bis-(1,1-dimethylethyl) }\end{array}$ & \\
\hline & $\begin{array}{l}\text { Benzene, } \\
\text { 1,4-bis-(1,1-dimethylethyl) }\end{array}$ & \\
\hline \multirow[t]{2}{*}{25.30} & 1H-indole-3-acetonitrile & 1H-indole-3-acetonitrile, 1-(trimethylsilyl)- \\
\hline & $\mathrm{N}$-(trifluoroacetyl)-glycine & Glycine, N-(trifluoroacetyl)-, trimethylsilyl ester \\
\hline 28.50 & 2,6-Di-tert-butylphenol & Trimethyl(2,6-ditert-butylphenoxy)silane \\
\hline \multirow[t]{2}{*}{34.31} & 2-Methyl-1-hexadecanol & \\
\hline & 2-Octadecayloxy-ethanol & \\
\hline 35.06 & 2-Methyl-1-hexadecanol & \\
\hline 36.59 & Myristic acid or C 14:0 & Tetradecanoic acid, trimethylsilyl ester \\
\hline 38.90 & Pentadecanoic acid or C 15:0 & n-Pentadecanoic acid, trimethylsilyl ester \\
\hline 41.29 & Palmitic acid or C $16: 0$ & Hexadecanoic acid, trimethylsilyl ester \\
\hline 45.56 & Stearic acid or C 18:0 & Octadecanoic acid, trimethylsilyl ester \\
\hline
\end{tabular}

